\title{
Latin American Racisms in Global Perspective
}

DOI:

10.4324/9781351047326-6

\section{Document Version}

Accepted author manuscript

Link to publication record in Manchester Research Explorer

\section{Citation for published version (APA):}

Wade, P. (2020). Latin American Racisms in Global Perspective. In J. Solomos (Ed.), Routledge International Handbook of Contemporary Racisms (pp. 78-89). Routledge. https://doi.org/10.4324/9781351047326-6

\section{Published in:}

Routledge International Handbook of Contemporary Racisms

\section{Citing this paper}

Please note that where the full-text provided on Manchester Research Explorer is the Author Accepted Manuscript or Proof version this may differ from the final Published version. If citing, it is advised that you check and use the publisher's definitive version.

\section{General rights}

Copyright and moral rights for the publications made accessible in the Research Explorer are retained by the authors and/or other copyright owners and it is a condition of accessing publications that users recognise and abide by the legal requirements associated with these rights.

\section{Takedown policy}

If you believe that this document breaches copyright please refer to the University of Manchester's Takedown Procedures [http://man.ac.uk/04Y6Bo] or contact uml.scholarlycommunications@manchester.ac.uk providing relevant details, so we can investigate your claim.

\section{OPEN ACCESS}


In The Routledge International Handbook of Contemporary Racisms, edited by John

Solomos, 78-88. London: Routledge. https://doi.org/10.4324/9781351047326-6

\title{
Latin American racisms in global perspective
}

Peter Wade

\begin{abstract}
This chapter explores the character of Latin American racisms and the way they have been shaped by ideologies and practices of mestizaje (biological and cultural mixture). The chapter traces the historical process of mixture that produced mestizos (mixed people) and also underpinned the idea of the mestizo nation, seen as founded on racial difference, but as having overcome racism through mixture. Claims to being "racial democracies" were, from the nineteenth century, made on a global stage and, after the Second World War, a global turn to anti-racism prompted social scientists to look at Brazil as a test case of racial democracy. Brazil failed the test and data accumulated documenting racial disadvantage and racism. However, mixture continued to obfuscate the operation of racism, by generating real experiences of racial conviviality. Post-1990 changes towards global trends in multiculturalism - and, from the early 2000s, towards an incipient naming of racism - altered the shape of mestizaje-based racial formations in Latin America, but did not displace them.
\end{abstract}

Keywords Latin America; racism; race; mestizaje (race mixture); racial democracy; multiculturalism; anti-racism

\section{Introduction}

An enduring feature of Latin American racial formations is mestizaje (mestiçagem in Portuguese). Translatable as mixture, the term refers to the processes of sexual and cultural interactions between Europeans, Africans and indigenous Americans that started in the sixteenth century and gave rise to substantial populations of "mestizos" - an umbrella term for people categorised as neither European, nor African nor indio (the Spanish colonial term for indigenous Americans), but something in between. Mestizo originally referred to the products of sexual interactions that mixed together razas (races), understood not so much as categories of people, but rather as lines of ancestry or "blood" (Banton 1987). But the term 
quickly acquired connotations of cultural mixture, with mestizos perceived to have inherited a combination of European, African and indigenous American habits.

Due to the colonial context, in which Europeans conquered, exploited and enslaved indigenous and African people, hierarchy always structured these interactions: "blood" and cultural traits perceived to be of African and indigenous origin were seen by the colonial powers as inferior to those considered as European: blackness/Africanness was strongly associated with enslavement; indigeneity was a vassal status; both were linked to barbarism and religious heterodoxy. Mestizaje was also structured by gender hierarchy, both in the sense that the European colonists were predominantly men who had sex with indigenous and African women, and in the ideological sense that nineteenth- and twentieth-century nationalist discourses highlighted masculine dominance in what was seen as the foundational creation of the populations that eventually formed nation-states.

In a global context, although colonialism everywhere gave rise to sexual and cultural mixture, only in Latin America did the process come to characterise a whole region in racial terms, and from the mid-nineteenth century to be widely - although not uniformly - adopted as national self-image, said by elites to differentiate the region's countries from other areas of the world, especially the Atlantic world. It is in relation to mestizaje that - still today - we have to grasp racism and the struggle against it.

\section{Processes of mixture}

Estimates are vague but, over the colonial period, probably less than 2 million Europeans arrived in Latin America; of these, under 30 percent were women. Some 6.5 million enslaved Africans were forcibly brought to the region, with men in the great majority. Once there, many of these Europeans and Africans mixed with each other and with indigenous peoples whose original numbers are uncertain, but who, by 1650, numbered about 6 million, having been depleted by disease and abuse (Marcílio 1984; Newson 1993; Sánchez-Albornoz 1984). By the late colonial period, a heterogeneous category of legally free people had emerged, recognised as intermediate between enslaved people, indios and whites. These people - many of whom were mestizos of diverse kinds - formed between a quarter (e.g. Mexico, Peru), a third (e.g. Brazil) and a half (e.g. Colombia) of the total population. Within a racial hierarchy dominated by whites, with enslaved and indigenous people at the bottom, the mestizo population was stratified according to multiple criteria, including occupation, wealth and racialised ancestry and appearance; complex nomenclatures attempted to organise this stratification. Historians have debated the role played in the stratification by what we might 
now call "race" (see Wade 2010: 28-29), but ideas about a person's "blood", often inferred from phenotype, were very important (Martínez 2008; Twinam 2015).

Between independence (which in most places occurred 1810-1830) and the midtwentieth century, more than 15 million European immigrants entered the region - of which 12 million went to Argentina and Brazil. There were much smaller numbers of immigrants from China, Japan and the Middle East. All over Latin America, governments and elites encouraged European immigration, while restricting non-white immigrants (and often Jews too), frequently through covert means. These policies obeyed both a colonially-derived ideology, which valued whiteness, and late nineteenth- and early twentieth-century eugenic thinking, which saw Europeans as biologically and culturally superior and able to offset the supposedly deleterious effects of African and indigenous contributions to the national mix (Appelbaum, Macpherson, and Rosemblatt 2003; FitzGerald and Cook-Martín 2014).

The colonial period had created regional patterns of racialised demography, with regions where the indigenous population remained an important presence and source of labour (the Andes, much of Meso-America) and regions where that population had declined and been mostly replaced by African and mestizo labour (Brazil, lowland Colombia, Venezuela, much of the southern cone). The independence period reshaped the regional racial demography somewhat by vastly expanding the white populations of Argentina and Brazil, creating in the former country a dominant image of whiteness and, in the latter, a sense of a society that, for all its mixture, was underlain by a division between coloured (black and brown) and white (Alberto and Elena 2016; Hofbauer 2006; Skidmore 1974).

\section{Ideologies of mixture}

Colonial and republican Latin American societies were highly racist. It is arguable that colonial Latin America formed the crucible for the ideas about "race" that came to dominate the Atlantic world. In fifteenth-century Iberia, concepts of limpieza de sangre (cleanliness of blood) were developed as a way to police the social order, keeping people who supposedly had raza de judio o moro (Jewish or Moorish "race", in the sense of blood or ancestry) out of certain occupations and subjecting them to the possibility of Inquisitorial investigation for religious heterodoxy. In the Americas, these ideas embraced African and indigenous ancestry and were used to police the emerging mixed social strata, both formally - not allowing people with such ancestry into certain occupations and regulating marriages involving them - and informally - discriminating against them in social and especially family circles (Martínez 2008; Wade 2009: 67-71, 88-94). In the republican era, nation-building elites saw black, 
indigenous and dark-skinned mestizo populations as a drag on the nation's progress, due to their "inferior" raza, understood as a biocultural whole combining "blood" and "civilisation" (Stepan 1991).

Despite this, from the mid- to late nineteenth century, elites began to make claims about the inherent links between mixture and democracy. In 1861, Colombian writer and politician José María Samper wrote of the "marvellous work of the mixture of races", believing it "should produce a wholly democratic society, a race of republicans, representatives simultaneously of Europe, Africa and Colombia, and which gives the New World its particular character" (Samper 1861: 299). In 1920, asking a conference audience "What is the result of this variety of races?", the Colombian medic Jorge Bejarano answered that it would bring "the advent of a democracy", because it was known that "the promiscuity of races, in which the element socially considered inferior predominates, results in the reign of democracies" (Jiménez López et al. 1920: 198). In Mexico, especially after the 1910 Revolution, the link between mixture, democracy and harmony was elevated into a national ideology, with the writer and politician José Vasconcelos as its chief proponent, lauding the advent of a universal "cosmic race", of which the Latin American mestizo was a precursor, embodying "the equality of all men by natural right [and] the social and civic equality of whites, blacks and indios" (Vasconcelos 1925: 16). In 1933, Mexico's Foreign Ministry, attempting to counteract complaints from China about Mexican legislation seen to be anti-Chinese, declared that the government did not have "any racial or class prejudice", because "the great Mexican family comes from the crossing of distinct races" (FitzGerald and Cook-Martín 2014: 236). In Brazil, the idea of "racial democracy" was explicitly developed during the populist dictatorship of Getúlio Vargas (1939-1945) and subsequently. It drew on the depiction of Brazil as a harmonious mixture of European, African and indigenous heritages, which had first been propounded by the writer Gilberto Freyre in the early 1930s (Burke and PallaresBurke 2008; Freyre 1933). Freyre believed that "miscegenation and the interpenetration of cultures - chiefly European, Amerindian and African culture ... have tended to mollify the interclass and interracial antagonisms developed under an aristocratic economy"; this meant that "perhaps nowhere is the meeting, intercommunication, and harmonious fusion of diverse or, even, antagonistic cultural traditions occurring in so liberal a way as it is in Brazil" (Freyre 1986: xiv, 78).

These claims were being made - explicitly or implicitly - on a global stage. The Mexican Foreign Ministry was, in the case cited, talking directly to China, but the main audience was the rest of the Americas and Europe. Contrasts were often made between Latin 
American countries and the United States, which, especially during the period under discussion, was seen as the home of racism, understood as involving violent racial hatred, clear segregation and taboos on racial mixture. Until about the 1920s, the United States and north-western Europe were also seen as the home of "hard" eugenics, embracing policies of sterilisation (which persisted until later in Nazi Germany). In contrast, Latin American "soft" eugenics generally advocated policies of social hygiene (Stepan 1991; Stern 2011). Latin American "racial democracy" was constructed in relation to North American "racial hatred". The Cuban independence hero, José Martí, in his celebrated essay, "Nuestra América" - first published in La Revista Ilustrada de Nueva York, addressing an international Spanishspeaking readership on the need for Latin Americans to counter the threat posed by "the formidable neighbour who does not know us" - said that in Latin America "there is no hatred between races, because there are no races" (Martí 1891). This oppositional counterpoint, in which Latin American elites took the moral high ground in the democracy stakes, helped gloss over the racism that existed in their countries (Guimarães 2007; Seigel 2009).

\section{Racism re-discovered?}

The reputation of Brazil as a racial democracy was sufficiently strong that, in the wake of the Second World War, it attracted the attention of UNESCO, which in 1949 had formed a committee to deliberate on the race concept. The committee been set up by UNESCO's social science division, then headed by the Brazilian Arthur Ramos, who recruited, among others, a Brazilian sociologist, Luiz de Aguiar Costa Pinto, and a Mexican physical anthropologist, Juan Comas. Other members of the first committee meeting included the black US sociologist Franklin Frazier and French anthropologist Claude Lévi-Strauss, who had both worked in Brazil. Although several committee members had inklings that all might not be rosy in Brazil's racial garden, the country was chosen because it seemed to have lessons to teach the rest of the world about racial conviviality (Maio 2001). UNESCO then coordinated a series of studies of race relations in urban and rural areas of the country. The focus was squarely on blackness and black-brown-white relations. Texts included Race Relations Between Blacks and Whites in São Paulo and The Integration of the Black in a Class Society (Bastide and Fernandes 1955; Fernandes 1964). Indigenous Brazil was only occasionally included (Wagley 1952) and questions of racism were almost entirely confined to the black-white context.

The upshot of the UNESCO studies was that racial democracy was a "myth" (Fernandes 1964) and that racism existed. Yet while the research provided lots of examples 
of racist stereotyping and plenty of anecdotal evidence from black people attesting to the impact of these stereotypes on their self-esteem and life chances, racism as a set of structures that shaped inequality and distributed privilege was less clearly documented. Fernandes got close with his depiction of a system of "accommodation", in which most black and brown people had been placed in the lowest social strata by slavery and colonialism and, postabolition, were trapped there by racial stereotypes and discrimination and by traditional paternalist relations with - mostly whiter - people in the strata above them. Racism was dissimulated and obfuscated by the limited individualistic upward mobility allowed by paternalism: many black and brown people denied the existence of racism, while whites also denied it or were indifferent to questions of racial difference. However, Fernandes also optimistically believed that a shift in Brazil away from paternalism towards a "competitive social order" (i.e. free market capitalism) would bring greater racial equality as black people became integrated into a class society.

This claim tapped into a key feature of the racial formation found in Brazil and other Latin American countries, which also obfuscates the role of racism: the fact that class and race tend to coincide. This allows evident racial inequality to be explained away by saying it is a matter of class not racial discrimination and that black (and indigenous) people are poor because of the legacy of slavery (or other past oppressions and neglect), not because of current racism. In Brazil (and in some other countries), the existence of a significant number of poor whites (or light-skinned mestizos) is also used to reinforce the "class not race" argument. Fernandes aligned himself with these arguments in assuming that, if class dynamics were to be liberated from the constraints of paternalism and allowed free rein in the capitalist market, black people would increasingly become upwardly mobile into the middle and upper classes, leaving behind the legacies of slavery and neglect.

But, post-UNESCO, research in Brazil from the 1970s began to demonstrate the structural dimensions of racism using census and survey data, which had traditionally included self-ascribed "colour" categories (the main ones being black, brown and white). Social scientists deployed the data to show that, while brown people (in the 1970s around $40 \%$ of the total) were intermediate between black (under 10\%) and white (about 55\%), in statistical terms it made sense to put black and brown together as a single category, which was systematically disadvantaged compared to whites. The data also showed that racism had an independent and on-going effect. For example, black university graduates earned less than white ones ten years after graduation. More broadly, racial differences in income-earning could not be fully explained by a combination of non-racial variables such as occupation, 
education, migrant status, age, etc.: racism had to be playing a role (Hasenbalg 1985; Lovell 1994, 2006; Silva 1985; Telles 2004).

Similar data are emerging from other countries, such as Colombia (Barbary and Urrea 2004; Urrea Giraldo and Viáfara López 2007) and Mexico (Flores and Telles 2012) and from region-wide studies, including ones that correlate social status with skin colour (rather than self-ascribed identities) (Telles and Project on Ethnicity and Race in Latin America 2014; Telles, Flores, and Urrea-Giraldo 2015). Fernandes' optimism about the competitive social order seems very misplaced: the structural disadvantage bequeathed by slavery and past neglect is not only very hard - perhaps impossible - to shake off, but is also inseparable from ongoing racism, which naturalises the link between racialised difference and structural disadvantage.

\section{Racism and mestizaje}

Fernandes did not link the features he identified in the Brazilian system of accommodation to the role played by mixture in the society - for him, black and brown people were in the same position. Another UNESCO researcher, Marvin Harris, argued in the 1960s and 70s that pervasive mixture in Brazil had created a society in which racial identities were ill-defined and ambiguity was maximised (Harris 1964, 1970). For him, this meant that "the issue of racial discrimination is scarcely a vital one" (1964: 63). Harris over-stated the case, but he put his finger on something that Fernandes passed over, which was the role of mestizaje in the racial formation. In Brazil and in Latin America more widely, mestizaje shapes racial formation in important ways: racism operates through it, but in a way that makes racism hard to recognise as such (Da Costa 2016; Moreno Figueroa and Saldívar 2016).

On the one hand, mestizaje is powerfully structured by ideas about the inferiority of blackness and indigeneity - associated with low status, backwardness and poverty - and the superior value of whiteness or, often, a light-skinned, not-quite-white mestizo-ness associated with wealth and modernity. These racialised hierarchies pervade the social order and structure people's behaviour and relationships. They correlate with inequalities in occupation, education, income, security, health and life expectancy, as shown by data from Brazil and elsewhere that document the position of black, indigenous and dark-skinned people. ${ }^{1}$ They underlie racist stereotypes and associated acts of stigmatisation (Lamont et al. 2016). They structure ideas about beauty, especially for women who are particularly marked by and sensitive to the negative values attached to the skin tones, hair textures and facial features associated with black and indigenous people (Edmonds 2007; Gordon 2013; Nichols 
2013; Rahier 1999). They enter into the intimate domains of the family, where they can guide decisions about romantic relationships and reproduction, and can differentiate in a finegrained way between darker and lighter siblings (Hordge-Freeman 2015; Moreno Figueroa 2012; Roberts 2012). Numerous studies attest to these patterns across Latin America. ${ }^{2}$

On the other hand, mestizaje creates a lived experience in which many people live in families and contexts where everyone is more or less "brown"; levels of racial segregation are relatively low, compared to the United States (Barbary and Urrea 2004; Telles 2004); and there is some flexibility in racial classifications, in that, while most people can agree on what a typical "black", "white" or "indigenous" person looks like and where they are likely to fit in the social structure, things are much more uncertain on the middle ground of brownness. Mestizaje creates a context in which, for many people, racial difference is a fact of life, but not a very salient one compared to what they perceive as the greater role played by differences of class and gender. Some scholars have characterised this situation by distinguishing between social realms in which race is more and less important. Describing a low-income neighbourhood of Salvador, Brazil, Sansone (2003: 52-53) argues that the residents perceive a "soft" domain of social relations, where "color is seen as irrelevant in the orientation of social and power relations" (street corners, parties, the neighbourhood, sports, and religion), and a "hard" domain, where it is considered important (interactions with the police, the world of work, and of marriage and dating). Telles (2004) likewise characterises Brazil in terms of the co-existence of "horizontal" and "vertical" social relations. The realms of friendship, the family, and the neighbourhood are marked by the strong presence of horizontal or convivial relations of interaction, mixture, and fairly equal exchange. In contrast, vertical relations of hierarchy and inequality are more obvious in the realms of work, education, health, housing, and politics. Interestingly, Sansone describes family as a hard area, while Telles says it is a domain of horizontality. This suggests that it is not easy to distinguish domains of interaction in this way and that, instead, hierarchy and conviviality are in tension in all domains, albeit with different balances in different contexts. For example, family relations are intimate sites where racial conviviality and racial hierarchy coexist (Wade 2009). Both aspects are immanent in mestizaje and in each other.

In sum, mestizaje has created in Latin America a long-standing example of what scholars of other regions have been identifying as new, neoliberal conjunctures of "postraciality" (Goldberg 2015; Lentin 2014), "racism without racists" (Bonilla-Silva 2003), or "raceless racism", in which racism has been "buried alive" (Goldberg 2008). In Latin America, people have long lived with situations in which racism, racial hierarchy and 
inequality exist hand-in-glove with the denial and, more often, the minimisation of these hierarchies and their delegitimation as matters unworthy of sustained attention, especially in terms of government policy, because they supposedly lead to counter-productive outcomes for society by focusing on "divisive" differences and thus causing more racism (often labelled as "racism in reverse" because these concerns challenge white and mestizo privilege). While in North America and Europe these minimisations and delegitimations are coinciding with neoliberalisation, Latin America shows us that they are actually deeply embedded in liberalism more generally, which has a constitutive tension between equality and hierarchy (Wade 2017).

\section{Racism, multiculturalism and anti-racism}

Since the 1990s, Latin American nations have apparently disrupted the dominance of regimes centred on mestizaje by undertaking legislative reforms that assert the multicultural or pluriethnic character of the nation. Driven by an uneasy combination of indigenous and Afrodescendant activism (drawing on long-standing traditions of resistance and invigorated by global decolonisation and anti-racist movements) and state agendas of co-optation and governance (guided by global redefinitions of democracy as including respect for difference), these reforms have given unprecedented recognition to indigenous and Afro-descendant minorities. Reforms have accorded minorities rights pertaining to land, education, prior consultation about development projects, and political and juridical autonomy; these rights have been uneven both across different countries and in terms of rights being more widely recognised for indigenous than Afro-descendant people (Hale 2005; Paschel 2016; Rahier 2012; Sieder 2002; Speed 2005).

This cultural recognition opens debates about the symbolic and socio-economic status of "cultural" minorities and thus might be thought to address issues of racism and racialised inequality. However, the discussion has more often focused on the need to recognise cultural difference and "diversity", mirroring familiar tensions in global debates about multiculturalism, which has been criticised as a co-optative top-down policy that divides subordinate groups and distracts attention from the structural racialised inequalities that affect them all (Hale 2018; Lentin and Titley 2011; Saldívar 2018). In some Latin American cases, similar neighbouring communities have mobilised as either "black" or "indigenous" to claim land rights, depending on contingent factors (French 2009); in other cases, indigenous and black people who in the past had collaborated over land claims have found it necessary to work separately to fit into state frameworks (Ng'weno 2007). The "multicultural turn" has 
resulted in some changes to racialised inequality - at least on paper. For example, legally constituted indigenous reserves in Colombia now account for about 30 percent of the national territory, while, on the basis of a 1993 law, Afro-Colombian communities had by 2014 obtained legal title to more than half the area of the country's Pacific coast region (Salinas Abdala 2014). But such changes have done little to shift the entrenched patterns of racialised inequality outlined earlier. Indeed, a backlash against land titling processes may be one reason why Afro-Colombians and indigenous people from the Pacific region are suffering massive and violent displacement: members of these communities figure disproportionately among Colombia's many internally displaced people and murder victims (Oslender 2007; Wade 2016).

From about 2010, there have been signs of a greater willingness to talk about racism, not only in state circles but also among social movements, many of which had avoided such talk, preferring to focus on cultural difference - a tendency particularly noticeable among indigenous activists, who see cultural differences as constitutive of their identities and claims to autonomy. There are indications that some indigenous activists are willing to adopt a discourse of racism, in the context of intensifying extractivist and agro-industrial economic enterprises, which, backed by neoliberal state policies, threaten indigenous lands and lives. Indigenous protest tends to provoke state and popular violence targeting indigenous bodies, which can elicit an indigenous discourse about racism as a systemic feature of the society. For example, the recent attempt by indigenous female leader María de Jesús Patricio (a.k.a. Marichuy) to become a presidential candidate for Mexico provoked a storm of abuse on social media that was so clearly racist in tone that anti-indigenous racism could hardly be ignored as an issue (Marini 2018). ${ }^{3}$

Still, the incipient emergence of racism as a topic of public debate has tended to centre around anti-black racism, partly because it has been led by Brazil, where racism had long been a central focus for the country's mostly urban - and culturally not very distinctive - black population. In 1995, the state officially recognised racism as a problem, sparking a series of reforms that from the early 2000 s led to race-based affirmative action measures in higher education admissions and later in federal employment, which provoked debates about "fairness" familiar from US and other contexts (Lehmann 2018). In Colombia, the state supported the National Campaign Against Racism (2009) and later, as part of the UN's International Decade of Afrodescendants (2015-2024), the Face Up to Racism campaign (2016). Several countries passed anti-discrimination legislation (Hernández 2013) and in a 
few cases this led to high-profile cases, such as that which saw an Ecuadorian army officer found guilty of racial hate crime for abusing a black recruit. ${ }^{4}$

These media campaigns and legal battles, while symbolically significant, are shortlived and arguably tokenistic, but they complement affirmative action measures that, following the Brazilian lead, aim to address structural issues of education and employment. For example, Ecuador's Ministry of External Relations has instituted policies to increase ethnic minority recruitment in the lower ranks of the diplomatic service. The jury is out on the long-term effects of these policies, which are partly a product of Latin America's "pink tide" - a region-wide shift to the left from 1998. Given the signs of a reverse tide heralded since 2015 by the election of several important right-wing leaders, who seem to be less open to policies of racial reparation, the future is looking precarious. For example, in 2018 Brazil elected right-wing president Jair Bolsonaro, who had declared that indigenous land rights are an obstacle to agribusiness and pledged to cut back affirmative actions favouring black people.

\section{Conclusion}

Recent changes in the Latin American panorama - the multicultural turn, the incipient naming of racism - seem to have dislodged mestizaje from its dominant position. However, these changes can be seen as modifying mestizaje regimes rather than displacing them. Mestizaje, although apparently a project of homogenisation, always had a subordinate space for blackness and indigeneity, whose existence, along with whiteness, is necessary for mestizaje to exist conceptually in the first place. So adapting to multiculturalism was not, in fact, too much of a stretch. Racism has always been an absent presence in mestizaje: there, but not there at the same time; always in operation, but obfuscated by class hierarchies, blurred racial identifications and middle-ground conviviality. So even the incipient calling out of racism can be accommodated to this dynamic to some extent. A fundamental destabilisation of mestizaje regimes would require a much more radical recognition of the pervasive and structural effects of racism. But this recognition has to be fought for, against more tokenistic acknowledgements and the tendency - seen in Mexico's national agency for the prevention of discrimination, CONAPRED - to relativise racism as just one more form of discrimination, alongside sexism, ableism, ageism, heterosexism, etc. (Lentin 2011). While it is paramount to grasp the intersectional dimensions of racism - particularly notable in mestizaje's reliance on sexist constructions of mixture - it is also necessary to comprehend 
racism's particular modes of operation, driven by colonial histories of conquest and enslavement.

\author{
Notes \\ ${ }^{1}$ On inequalities of occupation, income and education, see the references cited earlier in the main text; see also \\ CEPAL (2017), Del Popolo (2017). On security, see Amnesty International (2015), Vargas (2018), Wade \\ (2016), CODHES (2012). \\ ${ }^{2}$ For overviews, see de la Fuente and Andrews (2018), Hernández (2013), Wade (2010). \\ ${ }^{3}$ See also https://www.jornada.com.mx/2018/02/27/opinion/019a2pol \\ ${ }^{4} \mathrm{See}$ https://www.lapora.sociology.cam.ac.uk/michael-arce-case-first-ruling-hate-crime-ecuador.
}

\title{
Bibliography
}

Alberto, Paulina, and Eduardo Elena, eds. 2016. Rethinking race in modern Argentina. New York: Cambridge University Press.

Amnesty International. 2015. "You killed my son": homicides by military police in the city of Rio de Janeiro. London: Amnesty International.

Appelbaum, Nancy P., Anne S. Macpherson, and Karin A. Rosemblatt, eds. 2003. Race and nation in modern Latin America. Chapel Hill: University of North Carolina Press.

Banton, Michael. 1987. Racial theories. Cambridge: Cambridge University Press.

Barbary, Olivier, and Fernando Urrea, eds. 2004. Gente negra en Colombia, dinámicas sociopolíticas en Cali y el Pacífico. Cali, Paris: CIDSE/Univalle, IRD, Colciencias.

Bastide, Roger, and Florestan Fernandes. 1955. Relações raciais entre negroes e brancos em São Paulo. São Paulo: Editora Anhembí.

Bonilla-Silva, Eduardo. 2003. Racism without racists: color-blind racism and the persistence of racial inequality in the United States. Lanham, MD: Rowman \& Littlefield.

Burke, Peter, and Maria Lúcia G. Pallares-Burke. 2008. Gilberto Freyre: social theory in the tropics. Oxford: Peter Lang.

CEPAL. 2017. Situación de las personas afrodescendientes en América Latina y desafíos de políticas para la garantía de sus derechos. Santiago: CEPAL.

CODHES. 2012. Estadísticas históricas de desplazamiento. Consultoría para los Derechos Humanos y el Desplazamiento [cited 5 January 2015]. Available from http://www.codhes.org/index.php?option=com_si\&type=1. 
Da Costa, Alexandre Emboaba. 2016. Confounding anti-racism: mixture, racial democracy, and post-racial politics in Brazil. Critical Sociology 42(4-5):495-513.

de la Fuente, Alejandro, and George Reid Andrews, eds. 2018. Afro-Latin American studies: an introduction. Cambridge: Cambridge University Press.

Del Popolo, Fabiana. 2017. Los pueblos indígenas en América (Abya Yala): desafíos para la igualdad en la diversidad. Santiago: CEPAL.

Edmonds, Alexander. 2007. Triumphant miscegenation: reflections on beauty and race in Brazil. Journal of Intercultural Studies 28(1):83 - 97.

Fernandes, Florestan. 1964. A integração do negro na sociedade de classes. São Paulo: Universidade de São Paulo.

FitzGerald, David Scott, and David Cook-Martín. 2014. Culling the masses: the democratic origins of racist immigration policy in the Americas. Cambridge, MA: Harvard University Press.

Flores, René, and Edward Telles. 2012. Social stratification in Mexico: disentangling color, ethnicity, and class. American Sociological Review 77(3):486-494.

French, Jan Hoffman. 2009. Legalizing identities: becoming black or Indian in Brazil's northeast. Chapel Hill: University of North Carolina Press.

Freyre, Gilberto. 1933. Casa-grande \& senzala: formação da familia brasileira sob o regime de economia patriarcal. Rio de Janeiro: Maia \& Schmidt.

- 1986. The masters and the slaves: a study in the development of Brazilian civilization. Berkeley, CA: University of California Press.

Goldberg, David Theo. 2008. The threat of race: reflections on racial neoliberalism. Malden, MA: Wiley-Blackwell.

- 2015. Are we all postracial yet? New York: John Wiley.

Gordon, Doreen. 2013. A beleza abre portas: beauty and the racialised body among black middle-class women in Salvador, Brazil. Feminist Theory 14(2):203-218.

Guimarães, Antonio Sérgio. 2007. Racial democracy. In Imagining Brazil, edited by Jessé Souza and Valter Sinder, 119-140. Lanham MD: Lexington Books.

Hale, Charles R. 2005. Neoliberal multiculturalism: the remaking of cultural rights and racial dominance in Central America. PoLAR: Political and Legal Anthropology Review 28(1):10-28. . 2018. When I hear the word culture ... Cultural Studies 32(3):497-509.

Harris, Marvin. 1964. Patterns of race in the Americas. New York: Norton Library. 
- 1970. Referential ambiguity in the calculus of Brazilian racial terms. Southwestern Journal of Anthropology 27:1-14.

Hasenbalg, Carlos. 1985. Race and socioeconomic inequalities in Brazil. In Race, Class and Power in Brazil, edited by Pierre-Michel Fontaine, 25-41. Los Angeles: Center for Afro-American Studies, University of Califonia.

Hernández, Tanya Kateri. 2013. Racial subordination in Latin America: the role of the state, customary law, and the new civil rights response. Cambridge: Cambridge University Press.

Hofbauer, Andreas. 2006. Uma história do branqueamento ou o negro em questão. São Paulo: Editora UNESP.

Hordge-Freeman, Elizabeth. 2015. The color of love: racial features, stigma, and socialization in black Brazilian families. Austin, TX: University of Texas Press.

Jiménez López, Miguel, Luis López de Mesa, Calixto Torres Umaña, et al. 1920. Los problemas de la raza en Colombia. Bogotá: El Espectador.

Lamont, Michèle, Graziella Moraes Silva, Jessica Welburn, et al. 2016. Getting respect: responding to stigma and discrimination in the United States, Brazil, and Israel. Princeton: Princeton University Press.

Lehmann, David. 2018. The prism of race: the politics and ideology of affirmative action in Brazil. Minnesota: University of Michigan Press.

Lentin, Alana. 2011. What happens to anti-racism when we are post race? Feminist Legal Studies 19(2):159-168. . 2014. Post-race, post politics: the paradoxical rise of culture after multiculturalism. Ethnic and Racial Studies 37(8):1268-1285.

Lentin, Alana, and Gavan Titley. 2011. The crises of multiculturalism: racism in a neoliberal age. London: Zed Books.

Lovell, Peggy A. 1994. Race, gender and development in Brazil. Latin American Research Review 29(3):7-35.

—. 2006. Race, gender, and work in São Paulo, Brazil, 1960-2000. Latin American Research Review 41(3):63-87.

Maio, Marcos Chor. 2001. UNESCO and the study of race relations in Brazil: regional or national issue? Latin American Research Review 36(2):118-136.

Marcílio, Maria Luiza. 1984. The population of colonial Brazil. In The Cambridge History of Latin America: Volume 2: Colonial Latin America, edited by Leslie Bethell, 37-64. Cambridge: Cambridge University Press. 
Marini, Anna Marta. 2018. La normalidad racista del discurso público en México y el caso de Marichuy. Iberoamérica Social [cited 5 February 2019]. Available from https://iberoamericasocial.com/la-normalidad-racista-del-discurso-publico-en-mexicoy-el-caso-de-marichuy/.

Martí, José. 1891. Nuestra América. La Revista Ilustrada de Nueva York, 10 January.

Martínez, María Elena. 2008. Genealogical fictions: limpieza de sangre, religion, and gender in colonial Mexico. Stanford: Stanford University Press.

Moreno Figueroa, Mónica. 2012. "Linda morenita": skin colour, beauty and the politics of mestizaje in Mexico. In Cultures of colour: visual, material, textual, edited by Chris Horrocks, 167-180. Oxford: Berghahn Books.

Moreno Figueroa, Mónica, and Emiko Saldívar. 2016. "We are not racists, we are Mexicans": privilege, nationalism and post-race ideology in Mexico. Critical Sociology 42(45):515-533.

Newson, Linda A. 1993. The demographic collapse of native peoples of the Americas, 1492 1650. In The meeting of two worlds: Europe and the Americas 1492-1650, edited by Warwick Bray, 247-288. London: British Academy.

Ng'weno, Bettina. 2007. Turf wars: territory and citizenship in the contemporary state. Stanford: Stanford University Press.

Nichols, Elizabeth Gackstetter. 2013. 'Decent girls with good hair': beauty, morality and race in Venezuela. Feminist Theory 14(2):171-185.

Oslender, Ulrich. 2007. Violence in development: the logic of forced displacement on Colombia's Pacific coast. Development in Practice 17(6):752-764.

Paschel, Tianna S. 2016. Becoming black political subjects: movements and ethno-racial rights in Colombia and Brazil. Princeton: Princeton University Press.

Rahier, Jean. 1999. Body politics in black and white: señoras, mujeres, blanqueamiento and Miss Esmeraldas 1997-1998, Ecuador. Women and Performance: A Journal of Feminist Theory 21:103-119.

— ed. 2012. Black social movements in Latin America: from monocultural mestizaje to multiculturalism. New York: Palgrave Macmillan.

Roberts, Elizabeth F. S. 2012. God's laboratory: assisted reproduction in the Andes. Berkeley, CA: University of California Press.

Saldívar, Emiko. 2018. Uses and abuses of culture: mestizaje in the era of multiculturalism. Cultural Studies 32(3):438-459. 
Salinas Abdala, Yamile. 2014. Los derechos territoriales de los grupos étnicos: ¿un compromiso social, una obligación constitucional o una tarea hecha a medias? Punto de Encuentro 67:1-39.

Samper, José María. 1861. Ensayo sobre las revoluciones políticas y la condición social de las repúblicas colombianas (hispano-americanas): con un apéndice sobre la orografía y la población de la Confederación Granadina. Paris: Imprenta de E. Thunot y Cia.

Sánchez-Albornoz, Nicolás. 1984. The population of colonial Spanish America. In The Cambridge History of Latin America, Volume 2: Colonial Latin America, edited by Leslie Bethell, 1-35. Cambridge: Cambridge University Press.

Sansone, Livio. 2003. Blackness without ethnicity: constructing race in Brazil. Basingstoke: Palgrave Macmillan.

Seigel, Micol. 2009. Uneven encounters: making race and nation in Brazil and the United States. Durham, NC: Duke University Press.

Sieder, Rachel, ed. 2002. Multiculturalism in Latin America: indigenous rights, diversity and democracy. Basingstoke: Palgrave Macmillan.

Silva, Nelson do Valle. 1985. Updating the cost of not being white in Brazil. In Race, class and power in Brazil, edited by Pierre-Michel Fontaine. Los Angeles: Centre of AfroAmerican Studies, University of California.

Skidmore, Thomas. 1974. Black into white: race and nationality in Brazilian thought. New York: Oxford University Press.

Speed, Shannon. 2005. Dangerous discourses: human rights and multiculturalism in neoliberal Mexico. PoLAR: Political and Legal Anthropology Review 28(1):29-51.

Stepan, Nancy Leys. 1991. "The hour of eugenics": race, gender and nation in Latin America. Ithaca, N.Y: Cornell University Press.

Stern, Alexandra Minna. 2011. "The Hour of Eugenics” in Veracruz, Mexico: radical politics, public health, and Latin America's only sterilization law. Hispanic American Historical Review 91(3):431-443.

Telles, Edward E. 2004. Race in another America: the significance of skin color in Brazil. Princeton: Princeton University Press.

Telles, Edward E., and Project on Ethnicity and Race in Latin America. 2014. Pigmentocracies: ethnicity, race and color in Latin America. Chapel Hill, NC: University of North Carolina Press. 
Telles, Edward, René D. Flores, and Fernando Urrea-Giraldo. 2015. Pigmentocracies: educational inequality, skin color and census ethnoracial identification in eight Latin American countries. Research in Social Stratification and Mobility 40:39-58.

Twinam, Ann. 2015. Purchasing whiteness: pardos, mulattos, and the quest for social mobility in the Spanish Indies. Stanford: Stanford University Press.

Urrea Giraldo, Fernando, and Carlos Viáfara López. 2007. Pobreza y grupos étnicos en Colombia: análisis de sus factores determinantes y lineamientos de políticas para su reducción. Bogotá: Departamento Nacional de Planeación.

Vargas, João H. Costa. 2018. The denial of antiblackness: multiracial redemption and black suffering. Minneapolis: University of Minnesota Press.

Vasconcelos, José. 1925. La raza cósmica: Misión de la raza iberoamericana. Notas de viajes a la América del Sur. Madrid: Agencia Mundial de Librería.

Wade, Peter. 2009. Race and sex in Latin America. London: Pluto Press.

. 2010. Race and ethnicity in Latin America. 2nd ed. London: Pluto Press. 2016. Mestizaje, multiculturalism, liberalism and violence. Latin American and Caribbean Ethnic Studies 11(3):323-343.

- 2017. Liberalism and its contradictions: democracy and hierarchy in mestizaje and genomics in Latin America. Latin American Research Review 52(4):623-638.

Wagley, Charles, ed. 1952. Race and class in rural Brazil. Paris: UNESCO. 